\title{
Englannin yliopistojen aikuiskoulutuksen historiaa
}

John A. Blyth, English University Adult Education 1908-1958. The Unique Tradition. Manchester University Press 1983. 363 s.

Tulevaisuudessa Suomen korkeakoululaitoksen historian tutkijat saavat eteensä mielenkiintoisen tutkimushaasteen. Mitkä olivat perimmältään ne koulutus- ja yhteiskuntapoliittiset vaikuttimet, jotka johtivat suomalaisen korkeakoululaitoksen laajentamaan toimintaansa täydennyskoulutuksen ja avoimen korkeakouluopetuksen piiriin 1970- ja 1980-luvulla. Yliopistojen aikuiskoulutuksessa pitemmät perinteet omaavissa maissa vastaavanlaista ilmiötä on voitu tarkastella historiallisesta näkökulmasta. Englantilainen yliopistonopettaja John A. Blyth on tehnyt tällaisen tutkimuksen, tekijän mukaan maansa ainutlaatuisesta yliopistojen aikuiskoulutustraditiosta. Teos kattaa vuodet 1908-1958 ulottuen näin ajallisesti lähelle kuului- san Open Universityn suunnitteluprosessin aloittamista. Eurooppalaisesta aikuiskoulutuksesta ja sosiaalihistoriasta kiinnostuneille teos on esittelemisen arvoinen, vaikka onkin ilmestynyt jo muutama vuosi sitten.

Blythin teos on metodiselta otteeltaan historiantutkimusta, jonka tutkimustulokset perustuvat kirjallisiin, ensisijaisesti painettuihin lähteisiin. Tekijä kohdistaa huomionsa pääasiassa Englannin pohjoisosien teollisuusseutujen yliopistojen aikuiskoulutukseen. Kysymyksessä ovat Leedsin, Liverpoolin ja Manchesterin yliopistot. Valintaansa Blyth perustelee sillä, että näiden yliopistojen asema varsinkin työväestölle tarkoitetussa luento- ja muussa opetuksessa oli keskeinen. Historiantutkijan tavoin Blyth peilaa kohdeyliopistojensa kehityslinjat Englannin yhteiskunnallisiin, poliittisiin ja yleisempien koulutusmahdollisuuksien muutoksiin eri vuosikymmeninä. 
Mikä tekee Englannin yliopistojen aikuiskoulutuksen perinteistä ainutlaatuisen? Blyth tuo esiin ainakin pari vastausta. Yliopistojen aikuiskoulutus organisoitiin yhteistyössä ammatillisen työväenliikkeen kanssa, tässä tehtävässä vuonna 1905 perustetulla Workers Educational Association -organisaatiolla (W.E.A.) oli merkittävä rooli. Toisaalta Blyth haluaa korostaa, että brittiläisessä traditiossa opiskelu itsensä vuoksi - ei tutkintojen - oli Englannin tunnusmerkki, mikä erotti sen esim. PohjoisAmerikasta. Kaiken kaikkiaan teoksen juonena voidaankin pitää sitä, kuinka Liberalistiset koulutusihanteet pitivät pintansa pragmaattisempien tavoitteiden noustessa voimakkaammin esiin 1900luvun edetessä.

Pääpiirteittäin Blythia tulkiten tässä kamppailussa kävi seuraavanlaisesti. Yliopistojen aikuiskoulutuksen alkaessa sen puolustajat uskoivat, että demokraattisessa yhteiskunnassa lukutaidon määrällisesti lisääntyessä liberalistinen, persoonallisuutta kehittävä koulutus oli ulotettava yhteiskunnan kaikkiin luokkiin. Ihmisen vapauttaminen ruumiillisen työn orjuudesta tapahtui - vaikkakin vain osin - opiskelun parissa. Kuvaavasti Englannin yliopistojen laajennusliike alkoikin tieteen historian luennoilla pohjoisen teollisuuskaupungeissa vuonna 1873. Järjestäjänä oli Cambridgen yliopiston Trinity College.

Ammattiyhdistysliikkeen ja yliopistojen yhteistyö luentojen ja pitempikestoisten yliopistokerhojen (university tutorial classes) organisoimisessa toi nopeasti liberalistiseen koulutuskäsitteeseen myös yhteiskunnallisen velvollisuuden aspektin: Työväestön oli tiedostettava asemansa teollistuvan yhteiskunnan jäseninä. Talous- ja yhteiskunnallisilla aineilla ja historian kursseilla olikin vahva jalansija aikuisväestön opetusohjelmissa pitkälle 1900-luvulle. 1920-luvulla yliopistoihin perustettiin aikuiskoulutusta varten erityisiä extra-muralosastoja, jolloin sekä luentomuotoisen opetuksen että useampivuotisten tutorialkerhojen määrä kasvoi. Tässä vaiheessa määrällinen kasvu eteni liberalististen ihanteiden vanavedessä. Vuonna 1924 annetuissa opetusministeriön ohjeissa kiellettiin julkinen rahoitus aikuiskoulutukselta, joka oli luonteeltaan ammatillista. Asennetta tuki konservatiivien poliittinen kärki rinnallaan W.E.A.:n johtomiehet. Pääministeri Lloyd George pelkäsi, että työnantajat vaatisivat valtiota maksamaan työntekijöidensä koulutuksen, kun taas ammattiyhdistysliikkeen puolella suhtautuminen ammatilliseen aikuiskoulutukseen oli luokkasidonnainen: koulutettu työläinen oli tehokkaampi ja sellaisenaan työnantajan taloudellisten intressien imettävissä.

Kansainvälisen lamakauden poliittiset vaikutukset aikuiskoulutuksen kenttään ovat Blythin esilletuomina mielenkiintoisia. Hallitus oli yhteiskuntarauhan nimissä huolestunut kasvavasta työttömyydestä, jota yritettiin lieventää perustamalla keskuksia, missä työttömät saivat "'laulaa lauluja, harjoittaa voimistelua ja tehdä käsitöitä’. Hallitus suosi myös yliopistojen itsensä tarjoamaa aikuiskoulutusta, koska se sen mielestä oli vähemmän dogmaattista. Lama näkyi myös opetuksen sisällöissä. Kun brittien matkustaminen ulkomaille väheni, järjesti Liverpoolin yliopisto kursseja matkailusta. Alpit, Ranska ja Etelä-Afrikka nähtävyyksineen koettiin matkan asemesta luentosalissa. Yleensäkin oppisisältöjen historiallisessa tarkastelussa Blyth havaitsee aikasidonnaisuuden. Jos matkailukursseja järjestettiin lamavuosina, nosti Hitlerin valtaantulo ja Saksan uhka kansainvälisten suhteiden luennot suosituiksi 1930luvun jälkipuoliskolla. 1930-luvulla voimistui myös keskustelu aikuiskoulutuksen sisällöllisistä painotuksista. Traditionalistit puolustivat edelleen humanismin pysyviä arvoja; Shakespeare oli ikuinen, kun taas ammatilliset taidot romuttuivat jokaisen teknologisen murroskauden mukana. Modernistit, joiksi Blyth nimittää käytännöllisemmän suunnan edustajia, kritisoivat liberalistista traditiota elitismistä. Yliopistojen aikuiskoulutuksesta saattoi hyötyä vain pieni vähemmistö. Opiskelijoiden ammatillista taustaa koskevista luvuista käykin ilmi, että opiskelijoista suuri osa jo 1900 -luvun alkupuolelta lähtien koostui varsinaisen työväenluokan ulkopuolelta.

Pragmaattisemman suunnan käytännön toteutukset vauhdittuivat toisen maailmansodan aikana ja sodan jälkeen. Vuonna 1940 Manchesterin yliopisto havaitsi, että ammatillisella kurssitarjonnalla oli suuret mahdollisuudet laajentaa yliopistojen aikuiskoulutusta. Kurssit "terveyttä tehtaassa" saivat lääkäreiden keskuudessa hyvän vastaanoton. Sodan jälkeen eri ammattiryhmien täydennyskoulutus käyttääksemme nykyistä terminologiaa vahvisti edelleen asemaansa yliopistojen toiminnassa. Ikääntyneet virkamiehet, lääkärit, yrittäjät jne. tarvitsivat lisäkoulutusta ja sen antamiseen menivät mukaan myös yliopistot.

Ammatillisesti orientoitunutta aikuiskoulutusta ei Blythin kirjan valossa tule kuitenkaan ylikorostaa. Sivistysihanteen tukijat ja ammattiyhdistysliikkeen koulutusperinteiden vaalijat pitivät pintansa vielä toisen maailmansodan jälkeen. Itse Winston Churchill puolusti humanististen arvojen merkitystä teknisen tietämyksen yläpuolella, vaikkakin hän samanaikaisesti näki, että tulevaisuus kuului sellaisille valtioille, jotka panostivat tieteellisen työn sovellutuksiin. Ulkomaankauppaan viitaten Blyth ihmette- 
lee, miksi "vie tai kuole" -iskulauseen maassa eivät luonnontieteet saaneet yliotetta yleisessä koulutuksessa.

Vastauksenkin tekijä aikuiskoulutuksen osalta esittää. Parlamentissa W.E.A.:n entisillä opiskelijoilla ja opettajilla oli poliittista valtaa vastustamaan tällaista kehitystä, joka oli vasten aikuiskoulutuksen historiallista taustaa.

Mutta tiukasta liberalististen perinteiden ortodoksisuudesta ammattiyhdistysliike ja sivistysyliopiston puolestapuhujat silti joutuivat luopumaan. Sodan jälkeen Englanti rakensi hyvinvointivaltiota, jolloin yhteiskunnallinen korostus aikuiskoulutuksessa joutui väistymään. Tämä näkyi kurssisisällöissä yhteiskunnallisten aineiden suhteellisesti vähentyessä. Vaikka kulttuuri- ja taideaineiden suosio lisääntyi, iskostui koulutuksesta käytyyn keskusteluun 1950-luvun puolivälissä myös "teknologisen humanismin käsite", jolla kaupallisen, teknisen ja tieteellisen yhteiskunnan kannattajat pyrkivät liberalisoimaan teknistä ja ammatillista aikuiskoulutusta. Vuoden 1954 aikuiskoulutuskomitean johtaja tohtori Eric Ashby saattoikin todeta, että "perinteinen humanismi oli tullut impotentiksi". Englanti siirtyi experttien ja teknokraattien aikakauteen, jolloin teknologia oli keskeinen osa yhteiskunnan filosofiasta. Ihmisen luovat teot näkyivät yhtä hyvin goottilaisissa kirkoissa kuin moderneissa lentokoneissakin. Vanha liberalistinen traditio adaptoitui näin 1950-luvun teknokraattien Englantiin.

Tuntematta Englannin aikuiskoulutuksen historiaa hyvin, ei Blythin teoksen hyviä tai heikkoja puolia voi objektiivisesti arvioida. Eräitä ajatuksia se silti herättää. Mikä on liberalistisen tradition asema nykypäivän '"kurjistuneessa" Englannissa? Nähtävästi Englannin vanhoissa yliopistoissa aikuiskoulutuksen tarina olisi erilainen kuin pohjoisen teollisuuskaupungeissa, missä yhteiskunnalliset muutokset välittyivät nopeammin yliopistojen muurien sisäpuolelle. Yhteiskunnallisia muutoksia peilaavan aikuiskoulutuksen historia mm. oppisisältöjen muutoksien suhten olisi mielenkiintoinen Suomenkin osalta. Ja lopuksi yksi analogia niille, jotka Suomen yliopistojen täydennyskoulutuskeskuksissa koke- vat läheiseksi tilanteen Englannista 1950-luvulta: "Harvat tärkeät ihmiset kaikissa yliopistoissa täysin tajuavat extra-mural-työn merkityksen... monet hyväksyvät sen, mutta tuskin uhraavat sille ajatustakaan; samalla kun jokaisessa yliopistossa on todennäköisesti muutamia professoreja, jotka vastustavat sitä".

Seppo Sivonen 